Jurnal Geografi, Edukasi dan Lingkungan (JGEL) Vol. 3, No. 1, Januari 2019:34-44

P-ISSN: 2579-8499; E-ISSN: 2579-8510

DOI: https://doi.org/10.29405/jgel.v3i1.2991

Website: http://journal.uhamka.ac.id/index.php/jgel

\title{
Kajian Risiko Bencana Kekeringan Di Kabupaten Cianjur
}

\author{
M.Galih Permadi ${ }^{1}$,dan Agung Adiputra ${ }^{2}$ \\ ${ }^{1}$ Fakultas Teknik Pertanian Universitas Musamus Marauke. \\ ${ }^{2}$ Program Studi Mitigasi Bencana Kerusakan Lahan Institut Pertanian Bogor. \\ *E-mail: galih@unmus.ac.id \\ Received: 09102018 / Accepted: 11122018 / Published online: 17012019
}

\begin{abstract}
ABSTRAK
Kejadian kekeringan merupakan masalah rutin di Kabupaten Cianjur yang perlu di tanggulangi melalui persiapan dan perencanaan. Penanggulangan kekeringan dapat diumlai dengan kajian risiko bencana, sehingga dapat mengurangi tingginya dampak kerugian. Kajian risiko bencana merupakan penilaian (assessment) pra bencana yang dilakukan dengan metode analisis keruangan melalui pemberian skor pada setiap parameter berdasarkan pada kontribusi relatif terhadap kekeringan. Parameter yang dipergunakan adalah curah hujan, ketersediaan sumber air, penggunaan lahan, jenis tanah dan kemiringan lereng. Hasil analisis menunjukkan wilayah dengan kelas bahaya tinggi seluas 23.263,4 ha, dan wilayah dengan tingkat bahaya sedang seluas 314.145,6 ha. Kekeringan umumnya terjadi di wilayah bagian selatan dan tenggara Kabupaten Cianjur yang lebih dekat ke arah laut. Beberapa faktor yang mempengaruhi adalah topografi wilayah yang tidak terjangkau pasokan air dari pegunungan, dan curah hujan yang lebih rendah dari wilayah utara. Wilayah yang memiliki kerentanan tinggi adalah Kecamatan Cidaun, Kecamatan Takokak, Kecamatan Sukaresmi, dan Kecamatan Naringgul. Keterpaparan menurut jarak dari ibukota kabupaten Cianjur adalah wilayah Karang Tanah sebagai yang terluas, disusul oleh Kecamatan Pacet dan Kecamatan Cibeber.
\end{abstract}

Kata Kunci: Risiko Kekeringan, Bahaya, Kerentanan, dan Keterpaparan.

\begin{abstract}
Drought is a routine problem in Cianjur Regency that needs to be addressed through preparation and planning. Counter measures begin with disaster risk assessment, so as to reduce the impact of losses that are too severe. Disaster risk assessment is a predisaster assessment carried out using spatial methods through weighted overlays and scoring of parameters based on contributions relative to drought. The results of the analysis show areas with hazard class highest covering an area of 23,263.4 ha and areas with moderate hazard levels covering an area of 314,145.6 ha. Drought is generally in the south and southeast of Cianjur Regency which is closer to the sea. Some of the factors that affect it are the topography of the area that is not affordable, the water supply from the mountains and lower rainfall from the northern region. Areas with high vulnerability are Cidaun Subdistrict, Takokak District, Sukaresmi District, and Naringgul District. Exposure according to distance from the town center of Cianjur
\end{abstract}


Jurnal Geografi, Edukasi dan Lingkungan (JGEL) Vol. 3, No. 1, Januari 2019:34-44

P-ISSN: 2579-8499; E-ISSN: 2579-8510

DOI: https://doi.org/10.29405/jgel.v3i1.2991

Website: http://journal.uhamka.ac.id/index.php/jgel

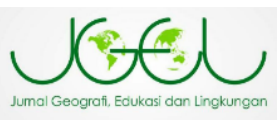

district is the Karang Tanah area as the widest, followed by the Pacet District and Cibeber District.

Keywords: Risk of Drought, Hazard, Vulnerability, and Exposure.

\section{PENDAHULUAN}

Musim kemarau identik dengan kondisi berkurangnya curah hujan, jika kondisi curah hujan pada musim kemarau berlangsung lebih panjang dari normalnya atau curah hujan berada di bawah normal, maka dipastikan pada beberapa wilayah seperti di Jawa Barat terjadi kekeringan. Hal ini terjadi terutama di daerah-daerah yang rawan mengalami kekeringan meteorogi dan kelangkaan air bersih. Kondisi tersebut berdampak lanjut pada menurunnya ketersediaan air untuk kebutuhan konsumsi masyarakat, maupun untuk pertanian. Menurut World Meteorological Organization (2012) dalam Supratono (2016), kekeringan merupakan salah satu variasi iklim yang lazim, dan dapat terjadi di segala zona iklim.

Rata-rata kejadian bencana di Indonesia selama tahun 2002-2016, menunjukkan bahwa kekeringan menempati urutan ke dua yaitu setelah kejadian banjir, dengan rata-rata kejadian sebanyak 156 kejadian per tahun (BNPB, 2016). Data indeks bencana BNPB 2016 mencatat kekeringan di Kabupaten Cianjur pernah terjadi pada 2014, 50 persen wilayah pertanian atau lebih dari 1.500 hektar areal persawahan mengalami kekeringan akibat curah hujan yang sangat rendah. Kekeringan meteorologi pada saat itu telah menjalar menjadi kekeringan hidrologi dan pertanian. Beberapa wilayah yang merupakan daerah rawan kekeringan adalah Kecamatan Agrabinta, Cidaun, Tanggeung, Kadupandak, Pasirkuda, Cianjur, Karang tengah, Sukaresmi, dan Haur-wangi.

Kejadian kekeringan merupakan masalah rutin yang membutuhkan penanggulangan melalui analisa kerawanan, sehingga dapat ditentukan langkah tepat dalam mengurangi dampak kerugian yang terlalu parah. Kajian risiko bencana kekeringan Kabupaten Cianjur menjadi modal utama dalam penanganan bencana ini. Kajian risiko bencana di kabupaten Cianjur ini bertujuan untuk memetakan bahaya kekeringan pertanian dan melakukan analisis kerentanan dan memetakan risiko kekeringan di Cianjur.

\section{METODE PENELITIAN}

Penelitian kajian risiko bencana kekeringan ini merupakan penelitian kewilayahan bersifat kuantitaif dengan data yang tidak diambil langsung dari lapangan atau secara sekunder menggunakan metode analisis spasial. Data spasial sekunder diperoleh dari penyedia data maupun pewali data resmi. Untuk mengetahui keabsahan hasil penelitian dilakukan survey lapangan.

\section{Waktu dan Lokasi Penelitian}

Kajian Risiko bencana kekeringan ini dilakukan di Kabupaten Cianjur, Provinsi Jawa Barat dengan Luas wilayah daratan 3.501,48 $\mathrm{Km}^{2}$. Kabupaten Cianjur terdiri dari 32 kecamatan dan terbagi menjadi 348 desa. Kajian ini dilakukan dari bulan Januari hingga Juli 2017.

\section{Alat dan Bahan}

Bahan yang digunakan dalam penelitian ini berkaitan dengan lokasi serta kajian kekeringan yang ada di Kabupaten Cianjur. Bahan penelitian berupa peta penggunaan lahan kabupaten Cianjur tahun 2014, peta curah hujan Kabupaten Cianjur, peta tanah, peta jaringan sungai dan drainase serta bahan 
Jurnal Geografi, Edukasi dan Lingkungan (JGEL) Vol. 3, No. 1, Januari 2019:34-44

P-ISSN: 2579-8499; E-ISSN: 2579-8510

DOI: https://doi.org/10.29405/jgel.v3i1.2991

Website: http://journal.uhamka.ac.id/index.php/jgel

lain yang dapat menunjang analisis kekeringan seperti data kependudukan untuk menganalisis kondisi kerentanan akibat kekeringan. Alat yang digunakan dalam kajian ini adalah laptop dengan perangkat lunak Arcgis 10 dengan kemampuan raster calculator yang mampu menghitung nilai data spasial dan Microsoft Office Excel.

\section{Teknik Analisis Data}

\section{Analisis Bahaya}

Analisis data dalam perhitungan bahaya kekeringan dilakukan analisis pembobotan data raster (weighted overlay). Data raster dengan satuan pixel diberikan skor dan pembobotan setiap pixel akan memiliki nilainya masingmasing. Tumpang tindih data raster menggunakan skala bobot sesuai kepentingannya sebagai parameter analisis dalam ini.

Penggunaan Weighted Overlay memiliki beberapa persyaratan diantaranya:

1. Data raster yang di input harus memiliki nilai integer. Suatu data raster floating-point atau yang memiliki nilai pecahan desimal terlebih dahulu harus dikonversi ke raster bilangan bulat, sebelum dapat digunakan dalam pengoolahan data secara weighted overlay. Perangkat reklasifikasi yang terdapat pada software Arcgis 10 menyediakan cara yang efektif untuk melakukan konversi data menjadi integer.

2. Setiap kelas nilai dalam raster yang di input diberi nilai baru berdasarkan pada skala evaluasi.

3. Setiap raster yang di input untuk penimbang diberi skor menurut kepentingan atau tingkat pengaruhnya. Bobot adalah persentase relative atau jumlah dari persentase pengaruh bobot yang semua parameternya harus sam-sama memiliki total skala 100.

Penentuan kriteria dan bahaya kekeringan di Kabupaten Cianjur, dilakukan penentuan parameter penyebab kekeringan dan memberikan masingmasing parameter tersebut bobot. Pada penelitian ini diperoleh 5 parameter yang paling berpengaruh terhadap bahaya kekeringan. 5 parameter tersebut diantaranya: Curah hujan, penggunaan lahan, sumber air (jaringan irigasi), jenis tanah, dan elevasi (kemiringan lereng). Parameter yang digunakan untuk menetukan bahaya kekeringan mengambil acuan yang disusun oleh Syarif (2013) dan Darojati (2015) yang dimodifikasi kembali sesuai dengan ketersediaan data yang ada.

Penilaian (assesment) dilakukan dengan cara pembobotan dan pemberian skor terhadap parameter yang digunakan dan didasarkan pada kontribusi relatif tiap parameter (besarnya potensi) tiap parameter terhadap kekeringan. Pembobotan pada penelitian ini merujuk pada rumusan yang digunakan oleh Ikra (2012) dalam BNPB (2016) sebagai berikut :

$$
\begin{aligned}
\mathrm{Wj}= & \mathrm{n}-\mathrm{rj}+1 \\
& \sum(\mathrm{n}-\mathrm{rj}+1)
\end{aligned}
$$

$\mathrm{Wj}$ adalah nilai bobot yang dinormalkan, $\mathrm{n}$ adalah jumlah parameter $(1,2,3 \ldots \mathrm{n})$ dan rj adalah posisi urutan parameter. Skor parameter indeks bahaya kekeringan dapat dilihat pada Tabel 1 dan 2:

Tabel 1. Skor masing-masing parameter

\begin{tabular}{llc}
\hline \multicolumn{1}{c}{ Parameter } & \multicolumn{1}{c}{ Kelas } & Skor/Kelas \\
\hline $\begin{array}{l}\text { Curah } \\
\text { Hujan }\end{array}$ & $>3000$ & 1 \\
(mm/thn) & $2500-3000$ & 2 \\
& $<2500$ & 3 \\
\hline Penggunaan & Tubuh Air, Hutan dan & 1 \\
Lahan & Semak Belukar & \\
& Perkebunan, Pertanian & 2 \\
& Lahan Kering &
\end{tabular}


Jurnal Geografi, Edukasi dan Lingkungan (JGEL) Vol. 3, No. 1, Januari 2019:34-44

P-ISSN: 2579-8499; E-ISSN: 2579-8510

DOI: https://doi.org/10.29405/jgel.v3i1.2991

Website: http://journal.uhamka.ac.id/index.php/jgel

\begin{tabular}{lll} 
& $\begin{array}{l}\text { Sawah, Pemukiman, } \\
\text { Lahan Terbangun dan } \\
\text { Terbuka, Tegalan }\end{array}$ & 3 \\
\hline $\begin{array}{l}\text { Sumber Air } \\
\text { (Jaringan }\end{array}$ & $0-250 \mathrm{~m}$ & 1 \\
Sungai) & $250-500 \mathrm{~m}$ & 2 \\
& $>500 \mathrm{~m}$ & 3 \\
\hline Tanah & Inceptisols, vertisols & 1 \\
& Ultisols, alfisols & 2 \\
& Entisols, Andisols & 3 \\
\hline Elevasi/ & $0-8 \%$ & 1 \\
Lereng & $8-15 \%$ & 1 \\
& $15-25 \%$ & 2 \\
& $25-40 \%$ & 3 \\
& $>40 \%$ & 3 \\
\hline
\end{tabular}

menghasilkan risiko kekeringan.

Kerentanan yang di analasis adalah kerentana sosial dan ekonomi (Tabel 3).

Tabel 3. Indikator dalam menentukan kerentanan sosial di Kabupaten Cianjur.

\begin{tabular}{|c|c|c|c|c|}
\hline $\begin{array}{l}\text { Kerenta } \\
\text { nan }\end{array}$ & Indikator & $\begin{array}{l}\text { Kelas } \\
\text { Indeks }\end{array}$ & Skor & Bobot \\
\hline \multirow{9}{*}{$\begin{array}{l}\text { Kerentan } \\
\text { an Sosial }\end{array}$} & Seks rasio & Rendah & 1 & \multirow{3}{*}{10} \\
\hline & & Sedang & 2 & \\
\hline & & Tinggi & 3 & \\
\hline & $\begin{array}{l}\text { Kepadatan } \\
\text { penduduk }\end{array}$ & Rendah & 1 & \multirow{3}{*}{30} \\
\hline & & Sedang & 2 & \\
\hline & & Tinggi & 3 & \\
\hline & Usia rentan & Rendah & 1 & \multirow{3}{*}{10} \\
\hline & & Sedang & 2 & \\
\hline & & Tinggi & 3 & \\
\hline \multirow{3}{*}{$\begin{array}{l}\text { Kerentan } \\
\text { an } \\
\text { Ekonomi }\end{array}$} & PDRB & $\begin{array}{l}\text { Hutan } \\
\text { Tanaman } \\
\text { Industri } \\
\text { (HTI) } \\
\text { dan } \\
\text { perkebun } \\
\text { an }\end{array}$ & 1 & \multirow{3}{*}{50} \\
\hline & & $\begin{array}{l}\text { Pertanian } \\
\text { lahan } \\
\text { kering } \\
\text { dan } \\
\text { sawah }\end{array}$ & 2 & \\
\hline & & $\begin{array}{l}\text { Pertanian } \\
\text { lahan } \\
\text { kering } \\
\text { campuran }\end{array}$ & 3 & \\
\hline
\end{tabular}

melalui weighted overlay mengacu pada rumusan Hadmoko et al (2010), seperti berikut di bawah ini:

$$
\begin{gathered}
\mathrm{LS}=\sum\{\mathrm{W}(\mathrm{a})+\mathrm{W}(\mathrm{b})+\mathrm{W}(\mathrm{c})\} \\
\ldots \ldots \ldots \ldots \ldots \ldots \ldots \ldots \ldots+\ldots+\cdots \\
\end{gathered}
$$

dimana LS adalah bahaya kekeringan, a,b,c....n adalah subparameter kekeringan dan $\mathrm{W}$ adalah bobot parameter yang dinormalkan. Tingkat bahaya kekeringan dikategorikan menjadi 3 zona yaitu zona aman, sedang dan tinggi, dan penentuan kelas bahaya didasarkan pada nilai interval yang diperoleh dari persamaan sebagai berikut (Dibyosaputro, 1999) yaitu:

Interval Kelas $=\underline{\text { Nilai Tertinggi }- \text { Nilai Terendah Interval }}$ Jumlah Kelas

\section{Analisis Kerentanan}

Pada analisis kerentanan terdapat 2 kerentanan yang dihitung untuk

Sumber : BNPB, 2016

Terdapat 3 parameter dalam kerentanan sosial dan hanya 1 paramater dalam kerentanan ekonomi, namun demikian dalam penelitian ini bobot di bagi merata pada 2 kerentanan tersebut, dengan $50 \%$ pada kerentanan sosial dan $50 \%$ pada kerentanan ekonomi.

$$
\begin{gathered}
\text { Kerentanan }=10(\mathrm{SR})+30(\mathrm{KP})+10 \\
(\mathrm{UR})+50(\mathrm{PDRB})
\end{gathered}
$$

\section{Atau}

Kerentanan $=50 \%$ kerentanan Sosial + 50\% Kerentanan Ekonomi

\section{Keterangan:}

$\begin{array}{ll}\mathrm{SR} & =\text { Seks rasio } \\ \mathrm{KP} & =\text { Kepadatan penduduk } \\ \mathrm{UR} & =\text { Usia rentan }\end{array}$


Jurnal Geografi, Edukasi dan Lingkungan (JGEL) Vol. 3, No. 1, Januari 2019:34-44

P-ISSN: 2579-8499; E-ISSN: 2579-8510

DOI: https://doi.org/10.29405/jgel.v3i1.2991

Website: http://journal.uhamka.ac.id/index.php/jgel

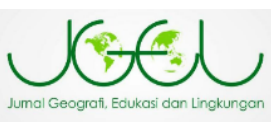

PDRB (kerentanan ekonomi, khususnya di sektor Hutan Tanaman Industri (HTI) dan perkebunan, Pertanian lahan kering dan sawah Pertanian lahan kering campuran)

Hasil dari peta juga akan dikelaskan menggunakan pembagian interval yang tertera pada analisis bahaya.

\section{Analisis Keterpaparan}

Peta keterpaparan pada dasarnya dihasilkan dari aspek politis yang mengutamakan kepentingan satu daerah atas daerah lainnya berdasarkan situs, fasilitas berharga, pusat administrasi, ataupun hal penting lainnya. Adanya keterbatasan data terhadap situs maupun fasilitas penting, analisis keterpaparan hanya dilakukan dengan pendekatan wilayah administrasi terpenting yaitu Ibukota Kabupaten Cianjur. Rentang yang digunakan untuk kelas keterpaparan dapat dilihat pada Tabel 4:

Tabel 4. Rentang kelas keterpaparan

\begin{tabular}{lll}
\hline No & Kelas & $\begin{array}{l}\text { Rentang/jarak } \\
\text { dari ibukota }\end{array}$ \\
\hline 1 & Kelas tiga/tinggi & 15 kilometer \\
2 & Kelas dua/sedang & $15-30$ kilometer \\
3 & Kelas satu/rendah & $>30$ kilometer \\
\hline
\end{tabular}

Dari tabel 4, diasumsikan bahwa semakin dekat wilayah tersebut dengan ibukota kabupaten, maka semakin tinggi pula tingkat keterpaparan wilayah tersebut. Rentang kelas keterpaparan dibuat dengan menggunakan buffer, kemudian hasilnya di- masukan pada skor parameter pemukiman. Asumsi yang dibangun adalah pemukiman dengan berbagai pusat ekonomi merupakan objek vital yang menjadi prioritas. Kedekatan dengan pusat pelayanan menyebabkan semakin padatnya penggunaan lahan pemukiman sehingga dapat diasumsikan pada wilayah tersebutlah kelas tertinggi dari keterpaparan.

\section{Analisis Risiko Kekeringan}

Analisis risiko kekeringan adalah hasil interaksi antara bahaya (hazard), kerentanan dan keterpaparan. Hasil analisis bahaya, kerentanan serta keterpaparan yang sebelumnya telah dilakukan, selanjutnya ditumpang tindihkan untuk mengetahui nilai risiko bencana kekeringan di wilayah tersebut. Formulasi yang digunakan untuk mendapatkan risiko kekeringan adalah:

$$
\mathrm{R}=\mathrm{H} \times \mathrm{V} \times \mathrm{E}
$$

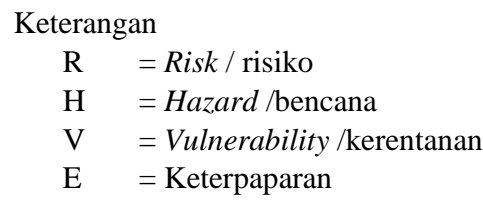

Untuk memudahkan kelas risiko bencana, masing-masing peta dibobot, karena pada dasarnya peta bahaya, kerentanan, dan keterpaparan masingmasing sudah memiliki kelas. Rumusan dan bobot yang digunakan adalah sebagai berikut:

$$
\mathbf{R}=\mathbf{3 5}(\mathbf{H})+\mathbf{3 5}(\mathrm{V})+\mathbf{3 0}(\mathrm{E})
$$

\begin{tabular}{|c|c|c|c|}
\hline Elemen Risiko & Kelas & Skor & Bobot \\
\hline \multirow{3}{*}{$\begin{array}{l}\text { Peta Bahaya } \\
\text { Kekeringan }\end{array}$} & Rendah & 1 & \multirow{3}{*}{35} \\
\hline & Sedang & 2 & \\
\hline & Tinggi & 3 & \\
\hline \multirow{4}{*}{ Peta Kerentanan } & Tidak rentan & 0 & \multirow{4}{*}{35} \\
\hline & Rendah & 1 & \\
\hline & Sedang & 2 & \\
\hline & Tinggi & 3 & \\
\hline \multirow{4}{*}{$\begin{array}{l}\text { Peta } \\
\text { Keterpaparan }\end{array}$} & Nol & 0 & \multirow{4}{*}{30} \\
\hline & Rendah & 1 & \\
\hline & Sedang & 2 & \\
\hline & tinggi & 3 & \\
\hline
\end{tabular}

Tabel 5. Elemen Risiko Bencana Kekeringan 
Jurnal Geografi, Edukasi dan Lingkungan (JGEL) Vol. 3, No. 1, Januari 2019:34-44

P-ISSN: 2579-8499; E-ISSN: 2579-8510

DOI: https://doi.org/10.29405/jgel.v3i1.2991

Website: http://journal.uhamka.ac.id/index.php/jgel

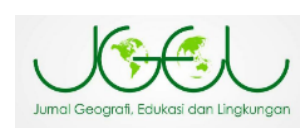

\section{HASIL DAN PEMBAHASAN Curah Hujan}

Berdasarkan data rata-rata tahunan stasiun curah hujan periode 1995-2015 sekitar wilayah Kabupaten Cianjur ratarata tahunan di Kabupaten Cianjur berkisar antara 2.500-4000 $\mathrm{mm}$ dengan jumlah hari hujan 150 hari pertahun. Curah hujan tertinggi (>4000 mm/tahun) terkonsentrasi di kawasan Gunung Gede bagian barat, di sekitar Cipanas. Adapun suhu udara Kabupaten Cianjur berkisar antara $15^{\circ}$. Suhu terendah terjadi di Cianjur bagian utara dan suhu tertinggi terjadi di Cianjur bagian selatan. Berdasarkan klasifikasi Oldeman, zona agroklimat di Kabupaten Cianjur dapat dikelompokkan berdasarkan kondisi fisiografinya, yaitu: (a) pada satuan dataran rendah dengan ketinggian $<500 \mathrm{~m}$ $\mathrm{dpl}$, temperatur udara berkisar antara $25.8^{\circ}-27.2^{\circ} \mathrm{C}$, curah hujan antara 1.000$4.500 \mathrm{~mm} /$ tahun, hujan tersebar merata, jumlah bulan basah antara 3-9 bulan basah per tahun; (b) pada satuan dataran tinggi dengan ketinggian $>500 \mathrm{mdpl}$, temperatur udara rerata $22^{\circ} \mathrm{C}$, curah hujan antara 3.000-4.000 mm/tahun, dan >9 bulan basah.

Iklim di Kabupaten Cianjur termasuk iklim tropis. Musim kemarau dimulai antara bulan April sampai Mei, dan memuncak pada bulan Juni sampai Agustus. Musim hujan dimulai pada bulan November atau Desember dengan angin barat dan barat laut yang berubah-ubah. Peralihan musim atau musim pancaroba terjadi pada bulan April dan Oktober. Rerata curah hujan selama 10 tahun terakhir sebesar $2.904 \mathrm{~mm} /$ tahun, dan jumlah hari hujan rata-rata 231 hari/tahun. Curah hujan bulanan tertinggi terjadi pada bulan Mei dengan rata-rata $584 \mathrm{~mm} /$ bulan dalam 23 hari hujan. Curah hujan terendah terjadi pada bulan Agustus dengan rata-rata $47 \mathrm{~mm} /$ tahun dalam 16 hari hujan (Gambar 1).

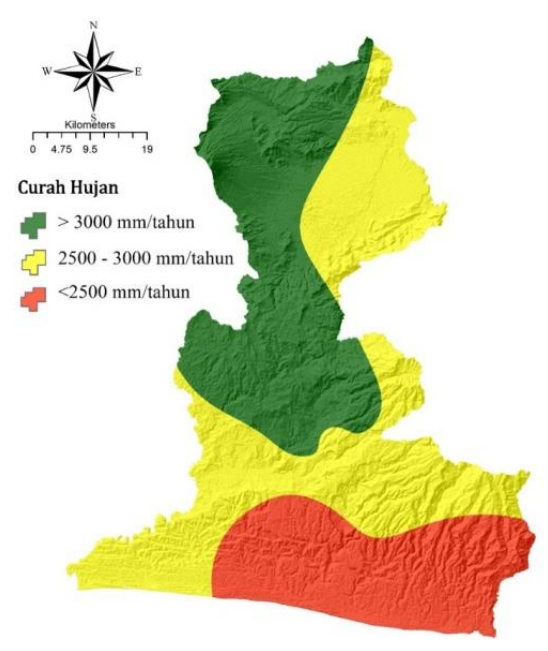

Gambar 1. Distribusi Curah Hujan Kab. Cianjur

\section{Jenis Tanah}

Bahan induk tanah di wilayah Kabupaten Cianjur sebagian besar terbentuk dari batuan beku dan sedimen. Tanah-tanah yang dijumpai di Kabupaten Cianjur diantaranya Alfisols, Andisols, Entisols, Inceptisols, Ultisols, dan Vertisols (Gambar 2).

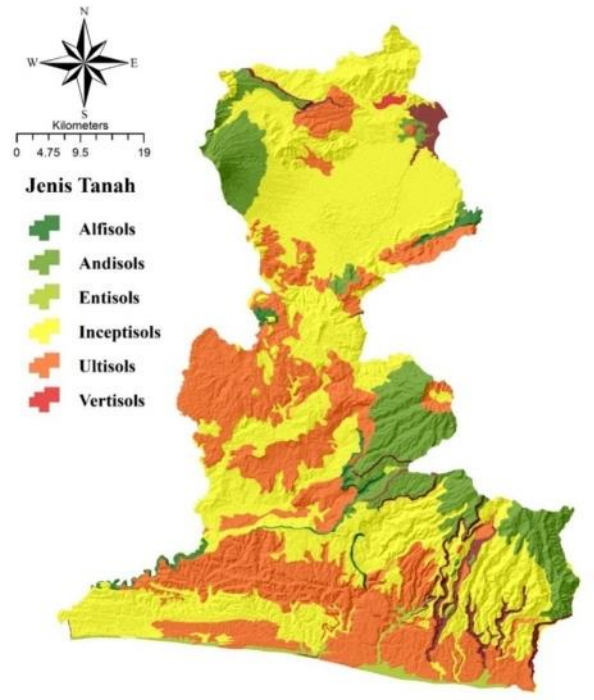

Gambar 2. Peta Jenis Tanah Kabupaten Cianjur 
Jurnal Geografi, Edukasi dan Lingkungan (JGEL) Vol. 3, No. 1, Januari 2019:34-44

P-ISSN: 2579-8499; E-ISSN: 2579-8510

DOI: https://doi.org/10.29405/jgel.v3i1.2991

Website: http://journal.uhamka.ac.id/index.php/jgel

\section{Penggunaan Lahan}

Beberapa penggunaan lahan yang dijumpai di Kabupaten Cianjur diantaranya hutan seluas 63.633 ha, pemukiman seluas 28.404 ha, perkebunan seluas 44.151 ha, pertanian lahan kering seluas 125.185 ha, sawah seluas 67.380 ha, semak belukar seluas 28.430 ha dan tubuh air dengan luas 2.688 ha (Gambar $3)$.

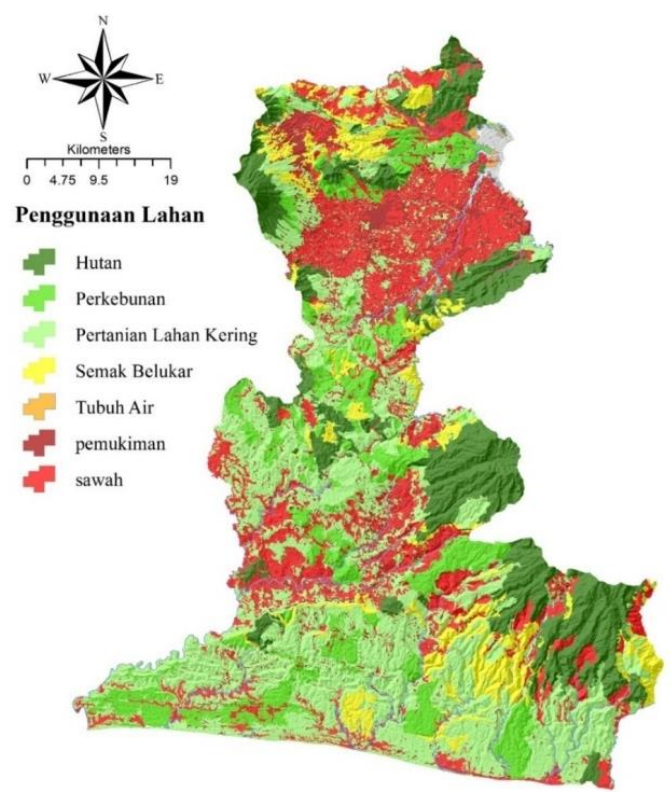

Gambar 3. Peta Penggunaan Lahan Kabupaten Cianjur

\section{Bahaya Kekeringan}

Penilaian bahaya berdasarkan bobot dan skor yang dilakukan dalam analisis ini adalah:

Bahaya kekeringan $=33(\mathrm{CH})+27(\mathrm{PL})$

$$
+20(\mathrm{TNH})+13(\mathrm{SA})+7(\mathrm{LRG})
$$

Keterangan:

$\mathrm{CH}=$ Curah Hujan

PL = Penggunaan Lahan

$\mathrm{SA}=$ Sumber air

$\mathrm{TNH}=$ Jenis Tanah

LRG = Lereng
Selanjutnya, dilakukan analisis tumpang tindih dengan menggunakan masing-masing nilai dan bobot dari parameter. Nilai hasil dari overlay tersebut di bagi menjadi 3 kelas. Hal ini dikarenakan pembagain kelas bahaya kekeringan di Kabupaten Cianjur dilakukan dengan membagi kepada kelas rendah, sedang dan tinggi. Berikut peta sebaran bahaya (hazard) kekeringan di Kabupaten Cianjur (Gambar 4).

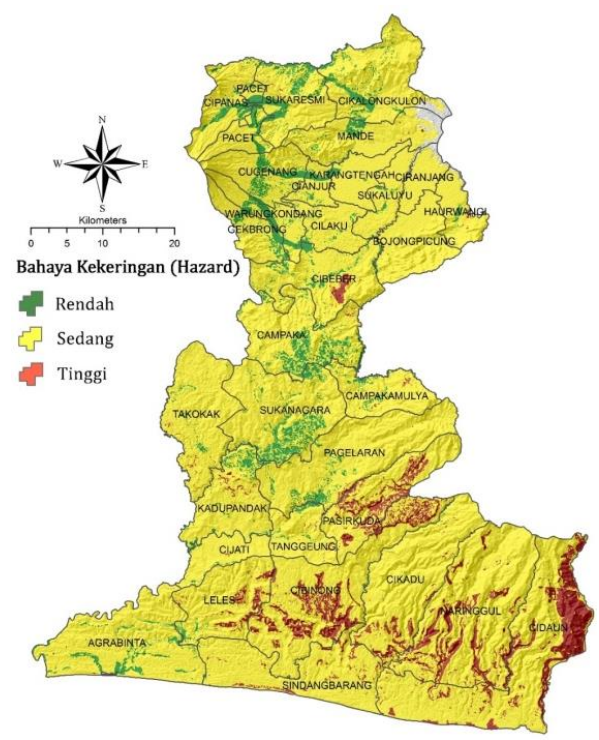

Gambar 4. Sebaran wilayah rawan Kekeringan di Kabupaten Cianjur

Berdasarkan peta di atas, diperoleh luasan wilayah kekeringan di Cianjur dengan bahaya kekeringan kelas 3 atau tertinggi seluas $23.263,4$ ha, bahaya kekeringan kelas 2 atau sedang seluas 314.145,6 ha dan wilayah dengan kekeringan kelas 1 atau rendah seluas 22.452,6 ha. Bahaya kekeringan di masing-masing kecamatan dapat dilihat pada tabel 6:

Tabel 6. Bahaya kekeringan pada masingmasing kecamatan di Kabupaten Cianjur

\begin{tabular}{lccr}
\hline Kecamatan & $\begin{array}{c}\text { Bahaya } \\
\text { Kelas 1 }\end{array}$ & $\begin{array}{c}\text { Bahaya } \\
\text { Kelas 2 }\end{array}$ & $\begin{array}{r}\text { Bahaya } \\
\text { Kelas 3 }\end{array}$ \\
\hline Agrabinta & 1589.25 & 18091.40 & 25.01
\end{tabular}


Jurnal Geografi, Edukasi dan Lingkungan (JGEL) Vol. 3, No. 1, Januari 2019:34-44

P-ISSN: 2579-8499; E-ISSN: 2579-8510

DOI: https://doi.org/10.29405/jgel.v3i1.2991

Website: http://journal.uhamka.ac.id/index.php/jgel

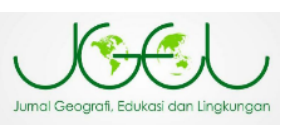

\begin{tabular}{|c|c|c|c|}
\hline Bojongpicung & 75.69 & 8727.90 & 6.20 \\
\hline Campaka & 2466.08 & 11821.86 & 44.26 \\
\hline Campakamulya & 543.03 & 6785.65 & 72.78 \\
\hline Cianjur & 456.52 & 2152.07 & \\
\hline Cibeber & 1140.49 & 10784.44 & 514.85 \\
\hline Cibinong & 55.57 & 18244.42 & 5183.64 \\
\hline Cidaun & & 23086.57 & 6755.55 \\
\hline Cijati & 220.40 & 4614.60 & 18.00 \\
\hline Cikadu & 84.03 & 17586.98 & 1148.55 \\
\hline Cikalongkulon & 1589.38 & 12259.71 & 5.83 \\
\hline Cilaku & 294.65 & 4946.55 & \\
\hline Cipanas & 900.49 & 5775.30 & 31.05 \\
\hline Ciranjang & 38.92 & 3084.05 & \\
\hline Cugenang & 1379.12 & 6213.36 & 3.19 \\
\hline Gekbrong & 824.33 & 4221.23 & 0.24 \\
\hline Haurwangi & 147.15 & 4291.43 & 36.09 \\
\hline Kadupandak & 1045.84 & 9175.74 & 213.01 \\
\hline Karangtengah & 187.44 & 4654.02 & \\
\hline Leles & 255.73 & 10100.92 & 1046.60 \\
\hline Mande & 648.77 & 8242.78 & 27.38 \\
\hline Naringgul & 5.64 & 23705.28 & 4311.60 \\
\hline Pacet & 863.11 & 3296.47 & 0.36 \\
\hline Pagelaran & 1017.97 & 18753.44 & 130.14 \\
\hline Pasirkuda & & 8814.06 & 2666.40 \\
\hline Sindangbarang & 24.54 & 15530.90 & 803.61 \\
\hline Sukaluyu & 210.44 & 4486.11 & \\
\hline Sukanagara & 2859.64 & 14504.12 & \\
\hline Sukaresmi & 1881.67 & 7264.89 & 44.38 \\
\hline Takokak & 330.89 & 13743.55 & 94.91 \\
\hline Tanggeung & 307.74 & 5583.66 & 75.13 \\
\hline Warungkondang & 983.87 & 3526.39 & 0.18 \\
\hline
\end{tabular}

\section{Kerentanan}

Analisis kerentanan di Kabupaten Cianjur menggunakan parameter seks rasio, kepadatan penduduk, usia rentan dan PDRB di Kabupaten Cianjur. Namun, fokus penelitian ini hanya pada dua kerentanan saja, yaitu kerentanan ekonomi dan kerentanan sosial. Terdapat 3 parameter dalam kerentanan sosial dan hanya 1 paramater dalam kerentanan ekonomi, namun demikian dalam penelitian ini bobot di bagi merata pada 2 kerentanan tersebut, dengan 50\% pada kerentanan sosial dan $50 \%$ pada kerentanan ekonomi seperti perhitungan berikut.

$$
\begin{gathered}
\text { Kerentanan }=10(\mathrm{SR})+30(\mathrm{KP})+10(\mathrm{UR})+ \\
50(\mathrm{PDRB}) \\
\text { Atau }
\end{gathered}
$$

Kerentanan $=50 \%$ kerentanan Sosial $+50 \%$ Kerentanan Ekonomi

Keterangan:

$$
\begin{array}{ll}
\mathrm{SR} & =\text { Seks rasio } \\
\mathrm{KP} & =\text { Kepadatan penduduk } \\
\mathrm{UR} & =\text { Usia rentan }
\end{array}
$$$$
\text { PDRB (kerentanan ekonomi, khususnya }
$$
di sektor Hutan Tanaman Industri (HTI) dan perkebunan Pertanian lahan kering dan sawah Pertanian lahan kering campuran)

Gambar 5 merupakan diagram bagaimana peta kerentanan sosial dan ekonomi diperhitungkan sebagai parameter dalam risiko bencana kekeringan.

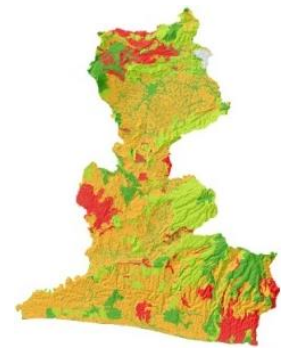

Kerentanan Ekonomi

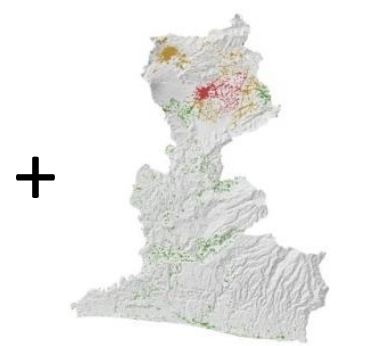

Kerentanan

Sosial
Gambar 5. Peta Kerentanan Ekonomi dan Kerentanan Sosial

Hasil analisis tumpang tindih dari penjumlahan nilai kerentanan ekonomi dan kerentanan sosial adalah kerentanan total. Hasil dapat dilihat pada Gambar 6 . 
Jurnal Geografi, Edukasi dan Lingkungan (JGEL) Vol. 3, No. 1, Januari 2019:34-44

P-ISSN: 2579-8499; E-ISSN: 2579-8510

DOI: https://doi.org/10.29405/jgel.v3i1.2991

Website: http://journal.uhamka.ac.id/index.php/jgel

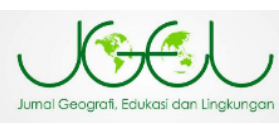

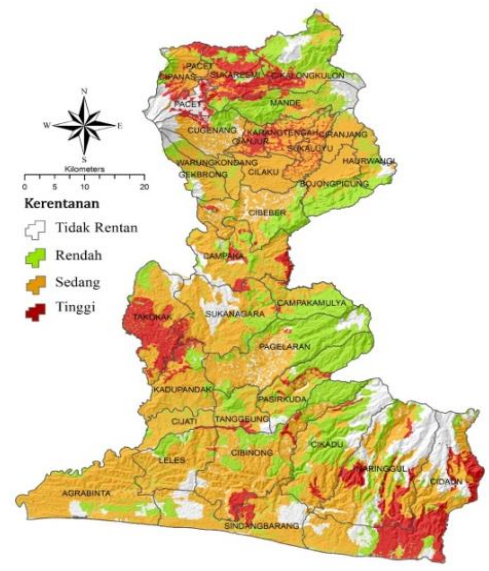

Gambar 6. Kerentanan di Kabupaten Cianjur

Berdasarkan Gambar 6, kerentanan tertinggi berada pada wilayah Kecamatan Cidaun dengan luas wilayah 9384 ha, Kecamatan Takokak seluas 6647,3 ha, Kecamatan Sukaresmi seluas 5786 ha dan Kecamatan Naringgul dengan luas 4454,8 ha. Apabila dicermati, pembobotan kerentanan sangat dipengaruhi oleh kerentanan ekonomi dengan parameter Hutan Tanaman Industri (HTI) dan perkebunan Pertanian lahan kering dan sawah Pertanian lahan kering campuran. Area-area ini umumnya sangat luas hingga hampir mencakup seluruh wilayah Cianjur, berbeda dengan kerentanan sosial yang hanya terfokus pada wilayah-wilayah pemukiman.

\section{Keterpaparan}

Seperti yang telah dikemukakan dalam metodologi, keterpaparan pada dasarnya dihasilkan dari aspek politis yang mengutamakan kepentingan satu daerah atas daerah lainnya berdasarkan situs, fasilitas berharga, pusat administrasi, ataupun hal penting lainnya. Adanya keterbatasan data terhadap situs maupun fasilitas penting, analisis keterpaparan hanya dilakukan dengan pendekatan wilayah administrasi terpenting yaitu Ibukota Kabupaten
Cianjur. Cakupan wilayah yang digunakan adalah $15 \mathrm{~km}$ untuk kelas 3, 15 sampai $30 \mathrm{~km}$ untuk kelas 2 dan lebih dari $30 \mathrm{~km}$ untuk kelas 3. Keterpaparan hanya mengambil area pemukiman sehingga di luar area pemukiman wilayah tersebut dianggap tidak memiliki kelas keterpaparan. Hasil dari pemetaan keterpaparan dapat dilihat pada Gambar 7.

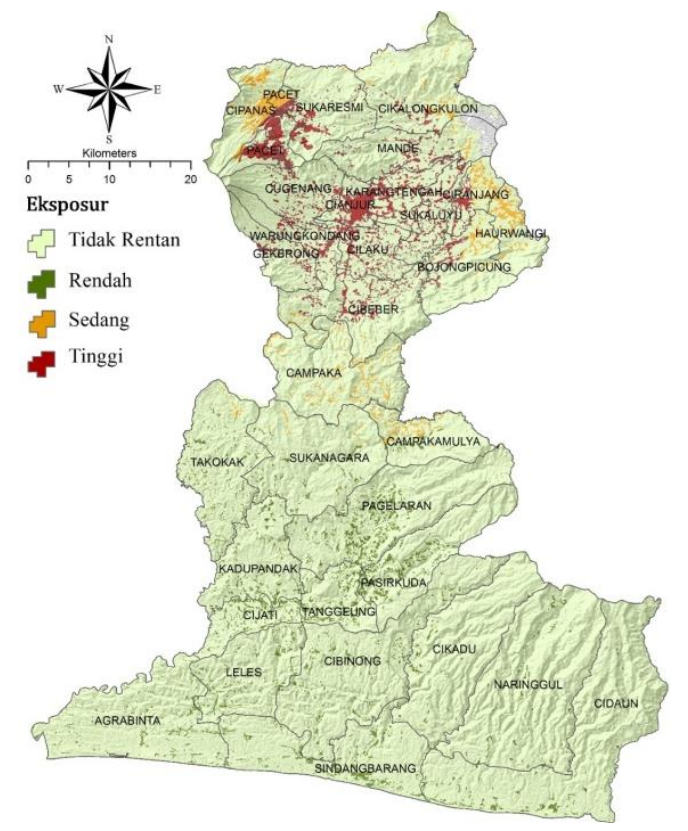

Gambar 7. Peta Keterpaparan di Kabupaten Cianjur

Wilayah dengan keterpaparan terluas adalah Kecamatan Karang Tengah seluas 1645,9 ha, Kecamatan Pacet seluas 1541,6 ha, dan Kecamatan Cibeber seluas 1378,6 ha.

\section{Risiko Bencana Kekeringan}

Berdasarkan hasil perhitungan risiko kekeringan, beberapa daerah yang memiliki tingkat risiko tinggi adalah Kecamatan Cidaun dengan luas 2640,3 ha, Kecamatan Karangtengah dengan luas 1606 ha, Kecamatan Cilaku dengan luas 1295,9 ha, dan Kecamatan Cianjur dengan luas 1274,6 ha. Berdasarkan luas wilayah risiko kekeringan, Kecamatan 
Jurnal Geografi, Edukasi dan Lingkungan (JGEL) Vol. 3, No. 1, Januari 2019:34-44

P-ISSN: 2579-8499; E-ISSN: 2579-8510

DOI: https://doi.org/10.29405/jgel.v3i1.2991

Website: http://journal.uhamka.ac.id/index.php/jgel

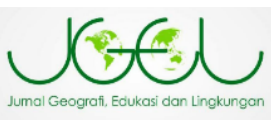

Cidaun menjadi daerah yang paling luas, hal ini tidak terlepas dari wilayahnya yang memang cukup besar di banding kecamatan-kecamatan yang berapa di daerah utara. Pada wilayah utara wilayah administrasi relatif lebih kecil, namun demikian sebaran risiko sebenarnya lebih tinggi dari wilayah tenggara (Gambar 8).

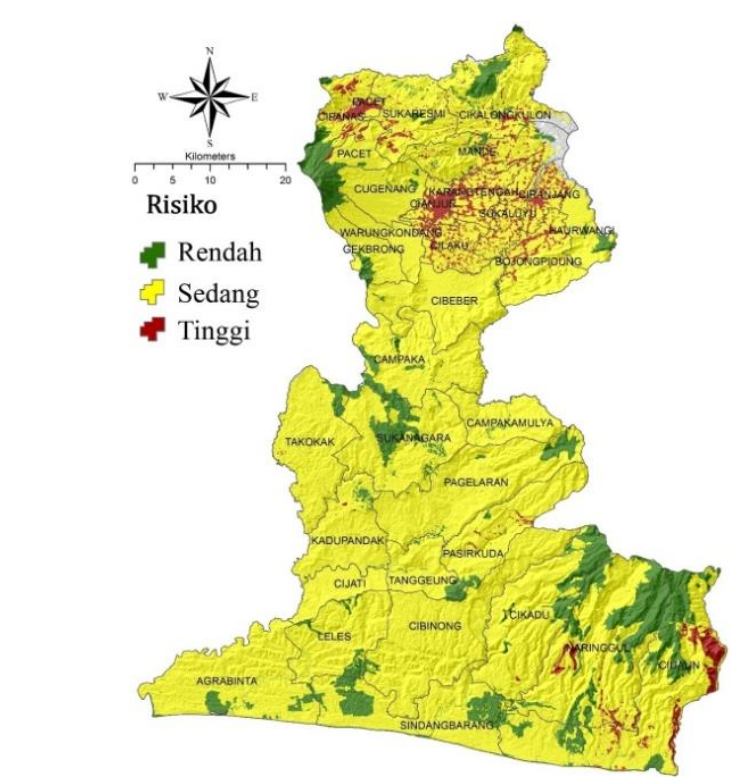

Gambar 8. Peta Risiko Bencana Kekeringan Di Kabupaten Cianjur

Wilayah utara Cianjur sebenarnya memiliki tingkat bahaya kekeringan yang relatif rendah dan sedang. Hasil analisis risiko menunjukkan bahwa daerah tersebut memiliki sebaran risiko yang tinggi di banding wilayah lain. Beberapa faktor yang mempengaruhi besarnya risiko di wilayah utara adalah adalah posisi wilayah yang cenderung padat dan menjadi pusat ibu kota kabupaten, sehingga kerentanan dan keterpaparan menjadi lebih tinggi. Peta kerentanan dan keterpaparan dominan mempengaruhi wilayah tersebut. Sebaran risiko kekeringan masing-masing kecamatan di Cianjur dapat dilihat pada tabel 7 .

Tabel 7. Risiko kekeringan pada masingmasing kecamatan di Kabupaten Cianjur

\begin{tabular}{|c|c|c|c|c|}
\hline No & Kecamatan & kelas 1 & kelas 2 & kelas 3 \\
\hline 1 & Agrabinta & 1623.3 & 18032.2 & \\
\hline 2 & Bojongpicung & 90.0 & 7644.1 & 1071.0 \\
\hline 3 & Campaka & 1286.2 & 12999.2 & 3.7 \\
\hline 4 & Campakamulya & 151.3 & 7243.6 & \\
\hline 5 & Cianjur & 11.4 & 1322.6 & 1274.6 \\
\hline 6 & Cibeber & 194.3 & 12235.8 & 0.2 \\
\hline 7 & Cibinong & 386.7 & 23095.0 & 1.6 \\
\hline 8 & Cidaun & 6941.8 & 20255.7 & 2640.3 \\
\hline 9 & Cijati & 89.0 & 4763.3 & \\
\hline 10 & Cikadu & 3819.1 & 14972.1 & 28.2 \\
\hline 11 & Cikalongkulon & 2500.0 & 10181.8 & 793.1 \\
\hline 12 & Cilaku & 7.5 & 3937.8 & 1295.9 \\
\hline 13 & Cipanas & 1666.7 & 3805.7 & 1211.2 \\
\hline 14 & Ciranjang & 59.5 & 1980.9 & 1082.6 \\
\hline 15 & Cugenang & 887.7 & 6701.2 & 3.3 \\
\hline 16 & Gekbrong & 833.7 & 4192.5 & 0.2 \\
\hline 17 & Haurwangi & 582.5 & 3889.7 & 0.6 \\
\hline 18 & Kadupandak & 518.9 & 9875.7 & 37.7 \\
\hline 19 & Karangtengah & 9.6 & 3225.6 & 1606.2 \\
\hline 20 & Leles & 1037.7 & 10365.5 & \\
\hline 21 & Mande & 757.0 & 6907.9 & 957.4 \\
\hline 22 & Naringgul & 8050.0 & 18983.7 & 981.6 \\
\hline 23 & Pacet & 587.1 & 3245.3 & 327.6 \\
\hline 24 & Pagelaran & 1204.6 & 18679.8 & \\
\hline 25 & Pasirkuda & 565.7 & 10703.4 & 210.7 \\
\hline 26 & Sindangbarang & 3938.8 & 12409.2 & 3.4 \\
\hline 27 & Sukaluyu & 44.7 & 3522.5 & 1129.4 \\
\hline 28 & Sukanagara & 3686.9 & 13662.4 & \\
\hline 29 & Sukaresmi & 412.9 & 8077.5 & 691.5 \\
\hline 30 & Takokak & 635.5 & 13400.3 & 40.2 \\
\hline 31 & Tanggeung & 492.7 & 5473.7 & 0.1 \\
\hline \multirow[t]{2}{*}{32} & Warungkondang & 474.8 & 4033.0 & 1.3 \\
\hline & Total & 43547.7 & 299818.8 & 15393.5 \\
\hline
\end{tabular}

\section{Kesimpulan}

Berdasarkan hasil penelitian, meskipun curah hujan di wilayah Kabupaten Cianjur termasuk kategori tinggi, masih terdapat beberapa daerah yang memiliki potensi tingkat risiko 
Jurnal Geografi, Edukasi dan Lingkungan (JGEL) Vol. 3, No. 1, Januari 2019:34-44

P-ISSN: 2579-8499; E-ISSN: 2579-8510

DOI: https://doi.org/10.29405/jgel.v3i1.2991

Website: http://journal.uhamka.ac.id/index.php/jgel

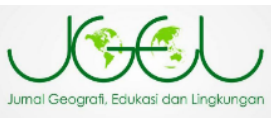

kekeringan tinggi. Hasil dari analisis weighted overlay menunjukkan wilayah yang masuk ke kelas rawan 3 (tertinggi) seluas $23.263,4$ ha dan wilayah dengan tingkat rawan sedang seluas 314.145,6 ha. Kekeringan umumnya berada di wilayah selatan dan tenggara Cianjur yang lebih dekat ke arah laut. Beberapa faktor yang mempengaruhi adalah topografi wilayah yang tidak terjangkau pasokan air dari pegunungan dan curah hujan yang lebih rendah dari wilayah utara.

Pada peta kerentanan, hasil yang diperoleh didominasi oleh kerentanan ekonomi dengan PDRB pertanian sebagai parameternya. Wilayah yang memiliki kerentanan tinggi adalah Kecamatan Cidaun, Kecamatan Takokak, Kecamatan Sukaresmi, dan Kecamatan Naringgul.

Peta keterpaparan hanya dinilai dari 1 parameter yaitu jarak dari ibukota kabupaten Cianjur. Berdasarkan penilaian ini wilayah Karang Tanah menjadi wilayah dengan keterpaparan terluas, disusul oleh Kecamatan Pacet dan Kecamatan Cibeber.

\section{DAFTAR PUSTAKA}

Arifin Z. 2010. Pola Spasial Kerentanan Bencana Alam (Studi Kasus Kabupaten Cianjur). Universitas Indonesia (ID). Jakarta

[BNPB] Badan Nasional Penanggulangan Bencana. 2012. Pedoman Umum Pengkajian Risiko Bencana. Jakarta (ID): BNPB

[BNPB] Badan Nasional Penanggulangan Bencana. 2016. Indeks Rawan Bencana Indonesia Tahun 2016. Jakarta (ID): BNPB.
Darojati, N.W. 2015. Pemantauan Bahaya Kekeringan dan Analisis Risiko Kekeringan di Kabupaten Indramayu. Tesis. Institut Pertanian Bogor (ID). Bogor

Handoko. 1994. Klimatologi Dasar. Jakarta (ID): Pustaka Jaya.

Husein Z. 2014. Analisis Kerentanan dan Risiko Banjir Terhadap Pertanian di Kabupaten Gorontalo. Tesis Institut Pertanian Bogor (ID). Bogor

Suprtono D. 2016 Pendugaan Potensi Kekeringan Meteorologis Terhadap Kebakaran Hutan dan Lahan dengan Metode Indeks Presipitasi Terstandarisasi di Kabupaten Banjar, Enviro Scienteae Vol. 12 No. 3, Nopember 2016 p.194-206 Universitas lambung mangkurat (ID). Kalimantan Selatan.

World Meteorological Organization (WMO). (2012). International Glossary of Hydrology, WMO no.385. Secretariat of the World Meteorological Organization. World Meteorological Organization. (2012). Standardized Precipitation Index User Guide. WMO-No.090. Geneva, (iD).

Yudarwati. 2016. Perubahan Penggunaan Lahan dan Arahan Pengendaliannya di Kabupaten Bogor dan Cianjur. Insttitut Pertanian Bogor. Bogor 